\title{
Disruptive Technology Adoption: An Empirical Investigation in Saudi Arabia
}

\author{
[ Shomool M. Al-Harbi, Dr. Afaf Bugawa, Prof. Soud Al Mahamid ]
}

\begin{abstract}
This study will use the technology-organizationenvironment (TOE) framework; which has been broadly used to clarify how to adopt technological innovation from the standpoint of a business (Tornatzky and Fleischer, 1990; Wu and Chen, 2014) and integrating it with the TAM Model which is modified to incorporate two factors such as perceived usefulness and perceived of ease to TOE framework which recognizes three factors that influence an organization's implementation of technological innovations directly, and they are technological dimension, organizational dimension, and environmental dimension. The link between these technological, organizational and environmental factors and technology adoption such as web services and 3D printers is a conception worth to examine and explore. Although, previous studies have acknowledged significant factors through TOE frame work that can encourage the adoption of 3D printer (CC Yeh, YF Chen, 2018), but as the study recommends that future researchers can add more factors or methods to investigate 3D printer adoption, therefore it's more effective to include the three factors with the TAM factors. The research will help to locate the effect of the three criteria's using TOE framework and TAM Model. In addition, Cost is a major player or a major mediator to these elements that will affect the 3D printer adoption decision, which will measure the readiness and acceptance to adopt and use this technology.
\end{abstract}

Keywords-3D Printer, Technology, Additive Manufacturing, TOE Framework, TAM Model, Technology Addoption, Innovation

\section{Introduction}

3D Printing is an enhanced manufacturing procedure that produces a physical object from a digital design and it can be defined as an assembly of digital manufacturing technologies, shaped into a three dimensional physical piece by adding any material layer by layer (West and Kuk, 2016; Sandström, 2016; Kwak et al., 2017). Regardless of the fact that the rate of $3 \mathrm{D}$ printing is fully rebel to the old-fashioned technologies of design and manufacturing, it has also created deep effects on many aspects, like economics, sociology, environment, demography, and security (Matias and Rao, 2015; Jiang et al., 2017; Xu et al., 2017). Related to the outdated technologies, 3D printing offers many benefits, like fast assembly, high accuracy, and product customization.

The potential of 3D printing really lies in the fact that it mainly decreases the interval time between equipment changes on a significant production line and allows for frequent innovations on an item throughout the manufacturing procedure; at the same time, the degree of customization of the resulting mass production is much advanced (Hasiuk, 2014;
Rayna and Striukova, 2016; Kapetaniou et al., 2018). The economic benefits from this technology include the further advancement and improvement of manufacturing, retailing, health care, and other aspects (Jia et al., 2016). A recent survey led by Allied Market Research (AMR) stated that the global 3D printing market was valued at US \$2.3 billion in 2013, increasing to US $\$ 8.6$ billion by 2020 at an annual rate (CAGR) of 20.6\% (Yeh, C. C., \& Chen, Y. F.. 2018).

Despite the fact that 3D printing has got many advantages for organizations, unfortunately it has not been commonly used, as related studies stated that the ratio of 3D printing in the manufacturing market is still less than 2\% (Wohlers and Gornet, 2014). Moreover, many industrial organizations are still struggled to include this promising technology into their production lines and merchandises' optimization. According to Ernst \& Young's Global 3D Printing Report 2016, 11\% of businesses in its surveys are testing and conduct experiment with 3D printing, while just 3\% claim important 3D printing experience and have a clear strategic strategy at the top management level for its upcoming application (Müller and Karevska, 2016).

As a result, the limited scale of adoption is astonishing considering the fact that 3D printing has been around since the 1980 s, and it appears that the implementation of 3D printing has revolved into a big challenge for companies. On one hand, the cost of 3D printing is grounded on both printing speed and printing materials. On the other hand, 3D printing applications have been restricted to several features, such as making prototypes or tailoring items for industry; in fact, the significant economic feature is that the cost of 3D printing is greater than that of traditional manufacturing (Despeisse et al., 2017). Under such concern, company's hesitation are set whether or not 3D printing is worth going for into manufacturing, related to other technologies. If they can't make additional profits from 3D printing, then they will not adopt it. Finally, the reason for this study is considering why the adoption rate are low, and the adoption for this innovation is rare, it is important to figure out the main reasons behind this.

Shomool M. Al-Harbi (Author)

Technology Management and Innovation / AGU

Bahrain

Dr. Afaf Bugawa (Co Author)

Prof. Soud Al Mahamid (Co Author) 


\section{Literature Review}

\section{A. Literature Review Summary}

1) Table I. has the most important Literature Review that this study was based on by using its limitations and recommendations.

TABLE I.

LITERATURE REVIEW

\begin{tabular}{|c|c|c|c|}
\hline \multirow{2}{*}{$\begin{array}{l}\text { Author \& } \\
\text { Year }\end{array}$} & \multicolumn{3}{|c|}{ Literature Review } \\
\hline & Methods & Findings & $\begin{array}{l}\text { Limitation/Recom } \\
\text { mendation }\end{array}$ \\
\hline $\begin{array}{l}\text { (Ching- } \\
\text { Chiang Yeh, } \\
\text { Yi-Fan Chen , } \\
\text { 2018) }\end{array}$ & $\begin{array}{l}\text { personal } \\
\text { (face-to-face } \\
\text { or by } \\
\text { telephone) } \\
\text { interviews }\end{array}$ & $\begin{array}{l}\text { cost and } \\
\text { environment are } \\
\text { the most } \\
\text { important factors } \\
\text { for the adoption } \\
\text { of } 3 D \text { printing }\end{array}$ & $\begin{array}{l}\text { Different } \\
\text { methodologies, } \\
\text { such as } \\
\text { longitudinal } \\
\text { studies and in- } \\
\text { depth interviews, } \\
\text { could also be } \\
\text { applied to identify } \\
\text { other possible } \\
\text { factors } \\
\text { influencing the } \\
\text { adoption of 3D } \\
\text { printing. Future } \\
\text { researchers can } \\
\text { investigate this } \\
\text { issue from the } \\
\text { perspective of } \\
\text { other factors }\end{array}$ \\
\hline $\begin{array}{l}\text { (Fu Jia a, b, } \\
\text { Xiaofeng } \\
\text { Wang c, } \\
\text { Navonil } \\
\text { Mustafee a, } \\
\text { Liang Hao d, } \\
\text { 2016). }\end{array}$ & $\begin{array}{l}\text { Business } \\
\text { Model } \\
\text { Innovation }\end{array}$ & $\begin{array}{l}\text { Whoever between } \\
\text { retailers and } \\
\text { chocolate } \\
\text { manufacturer } \\
\text { adopts the 3D } \\
\text { chocolate printing } \\
\text { technology first } \\
\text { will gain higher } \\
\text { profits than the } \\
\text { other. }\end{array}$ & $\begin{array}{l}\text { Future studies } \\
\text { could design } \\
\text { further models } \\
\text { based upon these } \\
\text { two basic ones in } \\
\text { order to capture } \\
\text { all the models in } \\
\text { the industry }\end{array}$ \\
\hline $\begin{array}{l}\text { (Elizabeth } \\
\text { Matias, } \\
\text { Bharat Rao } \\
\text { 2015) }\end{array}$ & $\begin{array}{l}\text { Interviews, } \\
\text { workshop, } \\
\text { IDEF0 } \\
\text { functional } \\
\text { modelling }\end{array}$ & $\begin{array}{l}\text { Designer's } \\
\text { knowledge is not } \\
\text { the only } \\
\text { important factor } \\
\text { in the adoption of } \\
\text { 3DP-RDM. To } \\
\text { promote radical } \\
\text { organizational } \\
\text { change }\end{array}$ & $\begin{array}{l}\text { Data collection } \\
\text { was limited to } \\
\text { single interviews, } \\
\text { almost always } \\
\text { with single } \\
\text { representatives. } \\
\text { Future research } \\
\text { would benefit } \\
\text { from } \\
\text { demonstrating } \\
\text { examples of 3DP- } \\
\text { RDM with non- } \\
\text { vertically } \\
\text { integrated models. }\end{array}$ \\
\hline $\begin{array}{l}\text { (Tunborg, Ida, } \\
\text { Svensson, } \\
\text { Emma, 2017). }\end{array}$ & $\begin{array}{l}\text { develop a } \\
\text { spare parts } \\
\text { classification } \\
\text { for 3D } \\
\text { printing } \\
\text { suitability }\end{array}$ & $\begin{array}{l}\text { The classification } \\
\text { illustrates that } \\
\text { spare parts with } \\
\text { low output in } \\
\text { terms of total } \\
\text { logistics costs, } \\
\text { object size, } \\
\text { material } \\
\text { requirements, } \\
\text { strength } \\
\text { requirements and } \\
\text { surface finish are } \\
\text { most suitable for } \\
\text { 3D printing }\end{array}$ & $\begin{array}{l}\text { One area that } \\
\text { might be of } \\
\text { interest to study is } \\
\text { what types of } \\
\text { costs should be } \\
\text { included when } \\
\text { comparing } \\
\text { conventional } \\
\text { manufacturing } \\
\text { and 3D printing. }\end{array}$ \\
\hline
\end{tabular}

\begin{tabular}{|c|c|c|c|}
\hline \multirow{2}{*}{$\begin{array}{c}\text { Author \& } \\
\text { Year }\end{array}$} & \multicolumn{3}{|c|}{ Literature Review } \\
\hline & Methods & Findings & $\begin{array}{l}\text { Limitation/Recom } \\
\text { mendation }\end{array}$ \\
\hline $\begin{array}{l}\text { (Hämäläinen } \\
\text { Mervi, Ojala } \\
\text { Arto, 2015) }\end{array}$ & interviews & $\begin{array}{l}\text { 3D printing } \\
\text { shortens the time } \\
\text { needed for } \\
\text { conventional } \\
\text { product design } \\
\text { and production, } \\
\text { enhancing the } \\
\text { overall } \\
\text { production cycle. }\end{array}$ & $\begin{array}{l}\text { Could aim at more } \\
\text { in-depth studies, } \\
\text { observing and } \\
\text { comparing } \\
\text { companies that } \\
\text { benefit from AM } \\
\text { technology, and } \\
\text { possible barriers } \\
\text { of AM usage. }\end{array}$ \\
\hline $\begin{array}{l}\text { (Lamperti } \\
\text { Fabio, } \\
\text { Cavedagna } \\
\text { Alessandro, } \\
\text { 2017) }\end{array}$ & $\begin{array}{l}\text { World Input- } \\
\text { Output } \\
\text { database } \\
\text { (WIOD) } \\
\text { framework }\end{array}$ & $\begin{array}{l}\text { A greater 3D } \\
\text { printer presence } \\
\text { is correlated with } \\
\text { a lower level of } \\
\text { GVC } \\
\text { participation }\end{array}$ & $\begin{array}{l}\text { Conduct a more } \\
\text { comprehensive } \\
\text { research on } \\
\text { patenting activity } \\
\text { around 3D printer, } \\
\text { retrieving data } \\
\text { also from other } \\
\text { patent offices than } \\
\text { USPTO. }\end{array}$ \\
\hline $\begin{array}{l}\text { (Alexandru } \\
\text { Pîrjan, Dana- } \\
\text { Mihaela } \\
\text { Petroşanu, } \\
\text { 2013) }\end{array}$ & $\begin{array}{l}\text { survey } \\
\text { research }\end{array}$ & $\begin{array}{l}\text { 3D printing } \\
\text { technology's } \\
\text { development and } \\
\text { spreading will } \\
\text { result in creating } \\
\text { new professions, } \\
\text { jobs and } \\
\text { industries }\end{array}$ & $\begin{array}{l}\text { Analyze further } \\
\text { the main available } \\
\text { additive } \\
\text { processes, the } \\
\text { advantages and } \\
\text { limitations of this } \\
\text { technology, to } \\
\text { compare the most } \\
\text { significant } \\
\text { existing 3D } \\
\text { printing solutions. }\end{array}$ \\
\hline
\end{tabular}

\section{B. Factors influencing $3 D$ printing implementation}

Research on the above mentioned field is just in its infancy. The exploratory research of (Mellor et al., 2014) on factors influencing 3D printing technology implementation revealed the following influences: external force, technological factors, organizational factors, strategic factors, operational factors, and supply chain. Muita, Westerlund, and Rajala (2015) noted that the implementation of quick manufacturing is affected by business issues like business models, industry features, and goods or service transitions, while other research regarded logistics as the least impacted area of this type of manufacturing. Moreover, Attaran (2016) pointed out the main obstacles for 3D printing implementation: technology, cost, and material. The size of produced goods, government regulations, and restrictions on cost also affect 3D printing implementation. On the basis of the technology recognition model, Wang, Sun, Cobb, Lawson, and Sharples (2016) clarified that both direct factors and influential effects influence 3D printing implementation for Chinese customers. In light of related research, 3D printing implementation is inclined to be affected by the outside environment where the professional firms reside. In addition, other research studies have focused on another actual factor specifically technology itself. Thus, more research should be keen to the starter of the adoption and analysis of business related factors for the issue of $3 \mathrm{D}$ printing application. 


\section{Technological dimension}

Technological dimension delivers internal and external effects of a technology's application in organizations. Bharadwaj (2000) revealed that information technology, functioning as a type of resource, only enhances competitiveness when it combines with or progresses preexisting resources or techniques. Therefore, in the procedure of technology implementation, technology infrastructure plays an essential role and also influences the eventual usage of 3D technology. 3D printers are able to combine technology perfectly with computer-aided design (CAD) software as well as other digital techniques such as magnetic quality imaging (Berman, 2012; Petrick and Simpson, 2013; Ludwig et al., 2014; Quan et al., 2015). Under this background, firms with a complex technology infrastructure are equipped with enough abilities for implementing 3D technology into their daily operation.

Previous research also noted that technological integration plays a positive function in IT implementation (Lin, 2009; Liu and Sun, 2011). Technological integration refers to the extent of the correlation between a firm's back-end information system and its record (Zhu et al., 2006). Therefore, it's an important to combine 3D printing with information systems that is critical for decision-makers within these business firms (Pearce et al., 2010; Mellor et al., 2014). If 3D printing is successfully related with the information systems of these organizations and with the information systems or lists of their exchange partners, then it can be determined that 3D technology will be cost effective. An organization's qualified advantage is also viewed as another critical element for new technology application and is distinct by investigative the purpose that 3D printing technology plays in reducing operational costs and in increasing relative corporate incomes. In this aspect, some advantages resulting from 3D printing application have been introduced (Petrick \& Simpson, 2013; Ford, 2014; Mellor et al., 2014; Thomas, 2015; Despeisse \& Ford, 2015). Hence, 3D printer will let organizations to create customized products in any quantities the want, making on demand product on site and it will allow them to do particularly customized designs for any client's requirement.

\section{Organizational dimension}

Organizational factors impact a company's purpose to develop new procedures (Hsiao et al., 2009). It talks about the different organizational circumstances, such as organizational readiness, that offers the base of support or barrier from the view of senior managers. Organizational readiness was examined in a previous study regarding technology implementation, occupations to measure whether or not companies are prepared with adequate technical or financial assets (Iacovou et al., 1995). Required technical resources designate a strong technical foundation, while commercial resources expose an organization's assets base available for technology investment by organizations (Sealy, 2011). Under this supply perspective, an establishment's 3D printing implementation can be reflected as a type of operational investment that may effect in the establishment of new manufacturing capabilities and business capacities (Cohen, 2014; Mellor et al., 2014).

Previous research stated that administrative obstacles also play important roles in effective technology implementation (Lin, 2009; Liu and Sun, 2011). One of the important reasons for 3D technology implementation is present in changing jobs or responsibilities, which bring important modifications in working practice and structure (Mellor et al., 2014). In this case, successfully preventing managerial obstacles is by effectively implementing of 3D printing. This will happen productively with the support from senior managers, and it is viewed as another factor for successful technology adoption (Cooper et al., 1990) and is associated with the considered goals, manufacturing procedure, or Research and ddevelopment approach of a firm (Mellor et al., 2014). Such management support is essential throughout technology implementation, because only under the circumstance of successful coordination across organizational units and combined perseverance of struggles (Chang et al., 2007) can the adoption be completed in positive ways. As a result, top management support is measured as a fundamental factor under this condition. In this aspect, some advantages resulting from 3D printing application have been introduced (Petrick \& Simpson, 2013; Ford, 2014; Mellor et al., 2014; Thomas, 2015; Despeisse \& Ford, 2015). Hence, 3D printer will let organizations to create customized products in any quantities the want, making on demand product on site and it will allow them to do particularly customized designs for any client's requirement.

\section{E. Environmental dimension}

Environmental factors are categorized into many aspects such as anticipations from market trends, trading partners, and government support, and all these are equally affecting the process of 3D technology implementation. Zhu et al. (2006) point out that it is important to realize the trade-offs in execution of a new manufacturing practice. Inadequate technical resources also experience some major difficulties for 3D printing implementation (Mani et al., 2014; Mellor et al., 2014; Ford, 2014; Quan et al., 2015). Nearly, the features of $3 \mathrm{D}$ printing are connected with its comparative immaturity in enhancement, and executives should as an outcome take these features into attention when making a decision on this precise technology adopting. Moreover, the environmental constructions bring an impact parallel with high-tech innovation by the fact that they depend on each other; an example of this influence is the effect of trading partners outside the organization.

Competitive pressure usually refers to definitely affect the factor of technology adoption (Jeyaraj et al., 2006). The influence conveys even stronger power when such adopting adds straight to market competition (Chong et al., 2009; Nelson et al., 2005; Wang et al., 2010; Zhu et al., 2006). Challenged with competitive pressure in the industry, some companies are obligatory to adopt 3D printing (Wang et al., 2010; Conner et al., 2015) in order to improve inventory, 
supply chain visibility, accurate data assembly, and operational effectiveness (Wang et al., 2010).

\section{F. Cost dimension}

Cost is also another crucial aspect for understanding the success of 3D printing. The cost is considered on the basis of different factors, including the fixed cost of printing resources, usage cost, and the cost for technological maintenance of the current arrangement. In addition, 3D printing adopting is associated with various forms of related investment, counting investment into hardware, software, or system integration (Baumers et al., 2016; Heath, 2015; Ruffo et al., 2007; Thomas, 2015; Allen, 2006). Based on the various and wide features of cost, organizations may comprehend a great amount of payments related to this type of development.

As an example and based on the interview with Boyle in (Matias, E., \& Rao, B., 2015), Shapeways, is a privately owned 3D printing service, offering customers and companies the opportunity to print or manufacture a product with one of their many 3D printers; they are considered one of the most remarkable companies in the $3 \mathrm{D}$ printing industry. Mainly since $46.77 \%$ of consumers are not willing to spend more than \$299 on 3D printer, and presently most users 3D printers cost about $\$ 2000$. Definitely this is why Shapeways is taking steps to teach customers with programs like "Made with Code", partnerships with companies like Hasbro, and outreach conferences at co-working spaces like the Wix. Until consumer 3D printers are at price that more consumers are prepared to pay, and the software is easier to use, they can operate a 3D printing service. This is a much more cost effective option, and users don't have to worry about the post processing or adjusting the 3D printer, and ever since 3D printing services are the greatest cost effective, Shapeways, and other 3D printing services, have the possible to make things easier with multiple 3D printing applications, including tinkering, personal manufacturing, on demand manufacturing, and small batch construction.

\section{Methodology}

This study looks to identify the main factors influencing the adopting of the 3D printer from several perspective of an organization. Using a Quantitative analysis, it will help knowing more about the obstacles that any organization faces to adopt new innovations and technology to its process. It is a mathematical and statistical method of studying behavior and predicting outcomes that investors and management use in their decision-making process. Quantitative methods emphasize objective measurements and the statistical, mathematical, or numerical analysis of data collected through polls, questionnaires, and surveys, or by manipulating preexisting statistical data using computational techniques. Quantitative research focuses on gathering numerical data and generalizing it across groups of people or to explain a particular phenomenon.

\section{Research Model (TOE Framework and TAM Model)}

Previous studies identified the technology-organizationenvironment (TOE) framework as a powerful tool for analyzing the basic factors when employing new technology in a given organization. Under this framework, researchers are interested to choose various organizational, technological, and environmental factors for various technologies, so that the TOE framework can be adopted in wider circumstances (Baker, 2012). On basis of TOE framework, this research establishes and analyzes an implementation model for 3D printing. The process by which a firm adopts and implements technological innovations is influenced by the technological context, the organizational dimension, and the environmental dimension (DePietro, Wiarda, \& Fleischer, 1990).

The technology dimension includes the internal and external technologies that are relevant to the firm. Technologies may include both equipment as well as processes. The organizational dimension refers to the characteristics and resources of the company, including the organization's size, degree of centralization, degree of formalization, managerial structure, human resources, amount of slack resources, and linkages among employees. The environmental dimension includes the size and structure of the industry, the firm's competitors, the macroeconomic element, and the regulatory environment (DePietro, Wiarda, \& Fleischer, 1990). These three elements present "both constraints and opportunities for technological innovation" (DePietro, Wiarda, \& Fleischer, 1990, p. 154). Thus, these three elements influence the way a firm sees the need for, searches for, and adopts new technology.

In addition, more studies recognize the Technology Acceptance Model as the first and primary traditional adoption theory in the field of IT (Awa, Eze, Urieto, \& Inyang, 2011; Benbasat \& Barki, 2007; Silva, 2007). It delivers base for unveiling the effects of external variables on adoption decisions with its basic claims resting firmly on economic, utilitarian, and attitudinal grounds. Moreover, TAM proposes perceived usefulness (PU) and perceived ease of use (PEOU) as the important determinants of IT adoption. An individual's intention to use an application is explained and predicted by his opinion of the technology's usefulness and its simplicity. The proponents of TAM posit that perceived usefulness is influenced by perceived ease of use and both predict attitudes (Davis, 1993).

Moreover, based on the literature review (Ching-Chiang Yeh, Yi-Fan Chen, 2018) which the researchers recommend that more factors or methods to be added to their TOE framework, we can formalize the research model and build it up with the TOE (Technology, Organization, Environment) framework as well as integrating TAM Model for more in depth results regarding adoption of 3D printer. 


\section{v. Data Collection}

This study is still under the process of gathering results and information, and with the help from the literature reviews this study will present four dimensions and several criteria's impacts on the adoption of 3D printing. To validate the appropriateness and independence of all criteria will be used; this study will apply the opinions from Dhahran Techno Valley experts in couple of departments to answers the raised questions. As a result, using the TOE framework and TAM Model to build up an additional extents or the adoption of 3D printing, which will help setting up a pair-wise assessment questionnaire as a survey for use. Moreover, by using the Quantitative methodology, this research will concern with testing the hypotheses derived from the TOE framework and TAM Model given and will be able to estimate the size of 3D printer adopting interest in businesses.

\section{Acknowledgment}

This study has been supported by Technology Management and Innovation Program in the Arabian Gulf University.

\section{References}

[1] Attaran, M. (2016). 3D Printing: Enabling a New Era of Opportunities andChallenges for Manufacturing.

[2] Awa, H. O., Ojiabo, O. U., \& Emecheta, B. C. (2015). Integrating TAM, TPB and TOE frameworks and expanding their characteristic constructs for e-commerce adoption by SMEs. Journal of Science \& Technology Policy Management, 6(1), 76-94.

[3] Baker, J. (2012). The technology-organization-environment framework. In Information systems theory (pp. 231-245). Springer, New York, NY.

[4] Baumers, M., Dickens, P., Tuck, C., \& Hague, R. (2016). The cost of additive manufacturing: machine productivity, economies of scale and technology-push. Technological forecasting and social change, 102, 193201.

[5] Berman, B. (2012). 3-D printing: The new industrial revolution. Business horizons, 55(2), 155-162.

[6] Benbasat, I., \& Barki, H. (2007). Quo vadis TAM?. Journal of the association for information systems, 8(4), 7.

[7] Bharadwaj, A. S. (2000). A resource-based perspective on information technology capability and firm performance: an empirical investigation. MIS quarterly, 169-196.Y. Yorozu, M. Hirano, K. Oka, and Y. Tagawa, "Electron spectroscopy studies on magneto-optical media and plastic substrate interface," IEEE Transl. J. Magn. Japan, vol. 2, pp. 740-741, August 1987 [Digests 9th Annual Conf. Magnetics Japan, p. 301, 1982].

[8] Chang, I. C., Hwang, H. G., Hung, M. C., Lin, M. H., \& Yen, D. C. (2007). Factors affecting the adoption of electronic signature: Executives' perspective of hospital information department. Decision Support Systems, 44(1), 350-359.

[9] Cohen, D. L. (2014). Fostering mainstream adoption of industrial 3D printing: Understanding the benefits and promoting organizational readiness. 3D Printing and Additive Manufacturing, 1(2), 62-69.

[10] Conner, B. P., Manogharan, G. P., \& Meyers, K. L. (2015). An assessment of implementation of entry-level 3D printers from the perspective of small businesses. Rapid Prototyping Journal, 21(5), 582597.

[11] Cooper, R. B., \& Zmud, R. W. (1990). Information technology implementation research: a technological diffusion approach. Management science, 36(2), 123-139.
[12] Davis, F. (1993) User acceptance of information technology: System characteristics, user perceptions and behaviour impacts. International Journal of Man-Machine Studies, 38, 475-487.

[13] Despeisse, M., Baumers, M., Brown, P., Charnley, F., Ford, S. J., Garmulewicz, A., ... \& Rowley, J. (2017). Unlocking value for a circular economy through 3D printing: A research agenda. Technological Forecasting and Social Change, 115, 75-84.

[14] Despeisse, M., \& Ford, S. (2015, September). The role of additive manufacturing in improving resource efficiency and sustainability. In IFIP International Conference on Advances in Production Management Systems (pp. 129-136). Springer, Cham.

[15] Depietro, R., Wiarda, E., \& Fleischer, M. (1990). The context for change: Organization, technology and environment. The processes of technological innovation, 199(0), 151-175.

[16] Ford, S. L. (2014). Additive manufacturing technology: potential implications for US manufacturing competitiveness. J. Int'l Com. \& Econ., 6, 40.

[17] Hämäläinen, M., \& Ojala, A. (2015). Additive manufacturing technology: Identifying value potential in additive manufacturing stakeholder groups and business networks.

[18] Hasiuk, F. J. (2014). Making things geological: 3-D printing in the geosciences. GSA Today, 24(8), 28.

[19] Hsiao, S. J., Li, Y. C., Chen, Y. L., \& Ko, H. C. (2009). Critical factors for the adoption of mobile nursing information systems in Taiwan: the nursing department administrators' perspective. Journal of medical systems, 33(5), 369.

[20] Heath, P. S. (2015). 3D Printing; Hardware and Software for the Consumer Market. International Journal of Students' Research in Technology \& Management, 3(8), 440-444.

[21] Hinton, T. J., Jallerat, Q., Palchesko, R. N., Park, J. H., Grodzicki, M. S., Shue, H. J., ... \& Feinberg, A. W. (2015). Three-dimensional printing of complex biological structures by freeform reversible embedding of suspended hydrogels. Science advances, 1(9), e1500758.

[22] Iacovou, C. L., Benbasat, I., \& Dexter, A. S. (1995). Electronic data interchange and small organizations: Adoption and impact of technology. MIS quarterly, 465-485.

[23] Jeyaraj, A., Rottman, J. W., \& Lacity, M. C. (2006). A review of the predictors, linkages, and biases in IT innovation adoption research. Journal of information technology, 21(1), 1-23.

[24] Jia, F., Wang, X., Mustafee, N., \& Hao, L. (2016). Investigating the feasibility of supply chain-centric business models in 3D chocolate printing: A simulation study. Technological Forecasting and Social Change, 102, 202-213.

[25] Jiang, R., Kleer, R., \& Piller, F. T. (2017). Predicting the future of additive manufacturing: A Delphi study on economic and societal implications of 3D printing for 2030. Technological Forecasting and Social Change, 117, 84-97.

[26] Kapetaniou, C., Rieple, A., Pilkington, A., Frandsen, T., \& Pisano, P. (2017). Building the layers of a new manufacturing taxonomy: How 3D printing is creating a new landscape of production eco-systems and competitive dynamics. Technological Forecasting and Social Change.

[27] Kwak, K., Kim, W., \& Park, K. (2017). Complementary multiplatform in the growing innovation ecosystem: Evidence from 3D printing technology. Technological Forecasting and Social Change.

[28] LAMPERTI, F., \& CAVEDAGNA, A. (2017). Additive manufacturing: determinants of adoption and effects on global value chain participation. A country-level analysis.

[29] Lin, L. C. (2009). An integrated framework for the development of radio frequency identification technology in the logistics and supply chain management. Computers \& Industrial Engineering, 57(3), 832-842.

[30] Liu, X., \& Sun, Y. (2011). Information Flow Management of VendorManaged Inventory System in Automobile Parts Inbound Logistics Based on Internet of Things. JSW, 6(7), 1374-1380.

[31] Ludwig, T., Stickel, O., Boden, A., \& Pipek, V. (2014, June). Towards sociable technologies: an empirical study on designing appropriation infrastructures for 3D printing. In Proceedings of the 2014 conference on Designing interactive systems (pp. 835-844). ACM. 
[32] Mani, M., Lyons, K. W., \& Gupta, S. K. (2014). Sustainability characterization for additive manufacturing. Journal of research of the National Institute of Standards and Technology, 119, 419.

[33] Matias, E., \& Rao, B. (2015, August). 3D printing: On its historical evolution and the implications for business. In Management of Engineering and Technology (PICMET), 2015 Portland International Conference on (pp. 551-558). IEEE.

[34] Mellor, S., Hao, L., \& Zhang, D. (2014). Additive manufacturing: A framework for implementation. International Journal of Production Economics, 149, 194-201.

[35] Muita, K., Westerlund, M., \& Rajala, R. (2015). The evolution of rapid production: How to adopt novel manufacturing technology. IFACPapersOnLine, 48(3), 32-37.

[36] Müller, A. and Karevska, S. (2016). EY's Global 3D printing Report 2016 (How will 3D printing make your company the strongest link in the value chain?). [online] Ey.com. Available at: https://www.ey.com/publication/vwluassets/ey-global-3d-printingreport-2016-full-report/\%24file/ey-global-3d-printing-report-2016-fullreport.pdf [Accessed 10 Sep. 2018].

[37] Nelson, M. L., Shaw, M. J., \& Qualls, W. (2005). Interorganizational system standards development in vertical industries. Electronic Markets, 15(4), 378-392.

[38] Pearce, J. M., Blair, C. M., Laciak, K. J., Andrews, R., Nosrat, A., \& Zelenika-Zovko, I. (2010). 3-D printing of open source appropriate technologies for self-directed sustainable development. Journal of Sustainable Development, 3(4), 17.

[39] Petrick, I. J., \& Simpson, T. W. (2013). 3D printing disrupts manufacturing: how economies of one create new rules of competition. Resea Pîrjan, A., \& Petroșanu, D. M. (2013). The impact of 3D printing technology on the society and economy. Journal of Information Systems \& Operations Management, 7(2), 360-370.rch-Technology Management, 56(6), 12-16.

[40] Quan, Z., Wu, A., Keefe, M., Qin, X., Yu, J., Suhr, J., ... \& Chou, T. W. (2015). Additive manufacturing of multi-directional preforms for composites: opportunities and challenges. Materials Today, 18(9), 503512.

[41] Ruffo, M., Tuck, C., \& Hague, R. (2007). Make or buy analysis for rapid manufacturing. Rapid Prototyping Journal, 13(1), 23-29.

[42] Silva, L. (2007). Post-positivist review of technology acceptance model. Journal of the Association for Information Systems, 8(4), 2.

[43] Thomas, D. (2016). Costs, benefits, and adoption of additive manufacturing: a supply chain perspective. The International Journal of Advanced Manufacturing Technology, 85(5-8), 1857-1876.

[44] Tornatzky, L. G., Fleischer, M., \& Chakrabarti, A. K. (1990). Processes of technological innovation. Lexington books.

[45] Tunborg, I., \& Svensson, E. (2017). Spare Parts Classification for 3D Printing Suitability.

[46] Wang, Q., Sun, X., Cobb, S., Lawson, G., \& Sharples, S. (2016). 3D printing system: an innovation for small-scale manufacturing in home settings?-early adopters of 3D printing systems in China. International Journal of Production Research, 54(20), 6017-6032.

[47] Wang, Y. M., Wang, Y. S., \& Yang, Y. F. (2010). Understanding the determinants of RFID adoption in the manufacturing industry. Technological forecasting and social change, 77(5), 803-815.

[48] West, J., \& Kuk, G. (2016). The complementarity of openness: How MakerBot leveraged Thingiverse in 3D printing. Technological Forecasting and Social Change, 102, 169-181.

[49] Wohlers, T., \& Gornet, T. (2014). History of additive manufacturing. Wohlers report, 24(2014), 118.

[50] Wu, H. H., Gilchrist, A., Sealy, K., Israelsen, P., \& Muhs, J. (2011, May). A review on inductive charging for electric vehicles. In Electric Machines \& Drives Conference (IEMDC), 2011 IEEE International (pp. 143-147). IEEE.

[51] Yee-Loong Chong, A., Ooi, K. B., Lin, B., \& Yi Tang, S. (2009). Influence of interorganizational relationships on SMEs'e-business adoption. Internet Research, 19(3), 313-331.
[52] Yeh, C. C., \& Chen, Y. F. (2018). Critical success factors for adoption of 3D printing. Technological Forecasting and Social Change.

[53] Zhu, K., Kraemer, K. L., \& Xu, S. (2006). The process of innovation assimilation by firms in different countries: a technology diffusion perspective on e-business. Management science, 52(10), 1557-1576. 